\title{
Nietzsche on Power and Value: A Response to John Richardson's Nietzsche's Values
}

\author{
Tsarina Doyle ${ }^{1}$
}

Abstract

This article offers a critical appraisal of the central arguments of John Richardson's Nietzsche's V alues. It contends that the book provides a comprehensive and illuminating interpretation of Nietzsche's naturalist approach to value but overlooks the more essentialist dimensions of his account of power.

\section{Introduction}

John Richardson's Nietzsche's Values is a comprehensive examination of the role of values in Nietzsche's philosophy. Offering a naturalistic account of values and arguing that he is an internalist and perspectivist about value, the book admirably combines patient analysis of Nietzsche's 'primary topic' (p. 1) with synthesizing his ideas into an overarching and tightly woven interpretation that extends to almost every aspect of his philosophy.

The book carefully situates its central argument in the context of current debates in Nietzsche studies. It stresses his naturalism over alternative Kantian-transcendental interpretations of Nietzsche on agency and power, in addition to contending, contrary to those who contest the claim, that Nietzsche's arguments regarding value can be fruitfully understood in terms of contemporary debates in meta-ethics. It is argued that Nietzsche is not a fictionalist and, against the usual 'realist-externalist cognitivism' alignment, that he adopts a 'perspectivist-internalist cognitivism' (33). In a somewhat similar vein to Clark and Dudrick's Sellarsian reading, ${ }^{2}$ the book holds that Nietzsche emphasizes our ability to justify our beliefs with reasons and, in partial agreement with recent constructivist interpretations, ${ }^{3}$ that these reasons can play the role of external-like constraints whilst being internal to our subjectivist framework of valuing. Although highly cognizant of the debates in the literature, the book's focus lies squarely on Nietzsche's texts throughout as it builds up the various naturalistic layers upon which it takes Nietzsche's approach to values to be founded.

\footnotetext{
${ }^{1}$ Tsarina Doyle, National University of Ireland, Galway. E-mail: tsarina.doyle@nuigalway.ie.

Tsarina Doyle is Lecturer in Philosophy at the National University of Ireland, Galway. She is the author of Nietzsche on Epistemology and Metaphysics: The World in View (Edinburgh University Press, 2009) and Nietzsche's Metaphysics of the Will to Power: The Possibility of Value (Cambridge University Press, 2018).

${ }^{2}$ Clark and Dudrick 2012.

${ }^{3}$ Silk 2015.
} 


\section{Nietzsche on Power and Value}

Although there is certainly much to admire in the book, I have some reservations about its non-essentialist understanding of Nietzsche's naturalism. Chiefly, I have misgivings about how it construes, in non-essentialist terms, Nietzsche's naturalistic account of values as constructions of intentionally directed drives that aim at the attainment of power. As closely argued as Richardson's argument is, it is informed by and relies upon a neoDarwinian, evolutionary and non-essentialist account of values and power in Nietzsche that conflicts with his more essentialist pronouncements about power. While Richardson is not unaware of Nietzsche's more essentialist side, he, nonetheless, downplays it in the service of his predominant neo-Darwinian thematic. Even though he is not the first to interpret Nietzsche's naturalism and account of values in neo-Darwinian and nonessentialist terms ${ }^{4}$ it is not clear to me that it is quite right to interpret Nietzsche's account of power non-essentially. In what follows, I will present the book's overarching argument before raising some questions about the particular naturalistic framework in which the argument is set. I will then assess the implications of adopting a more essentialist view for Richardson's interpretation of Nietzsche's account of the self and the reformation of our values, in addition to the constructivism and internalism that he attributes to Nietzsche.

\section{Overview of the central argument of the book}

Informing Richardson's naturalistic account of values in Nietzsche is his interpretation of Nietzsche's ontology of values along constructivist and evolutionary lines. According to his view, all values are genuine values in the descriptivist sense, and they 'have all been "constructed" back through human history by innovating valuers.' (34) Richardson thus rejects the view held by some commentators that only normative values are genuine values. Values, in his account, are made or constructed by the drives (34) and are signs that the drives steer by (96). Richardson adopts a telic account of valuing and values in the sense that values aim at power understood as growth in control (45). According to his reading, values are 'markers' that 'life sets down for itself in pursuit of power' (48) and they lend a specificity to willing by specifying what the growth in control will be in. Instead of an 'inchoate striving' (48), the drives 'channel the will to power into separate efforts, to growin-eating, to-grow-in-sex, to grow-in-parenting, to grow-in-social stature' (49). Nietzsche, accordingly, attributes minimal intentionality to all organisms in Richardson's account. The directedness of the drives is constituted by evolutionary selection rather than by 'mental fore-sighting of goals' or by 'conscious awareness of the intentional contents.' This means that all biological life can be understood as perspectival on the grounds of exhibiting a minimal “aboutness" in their mere responsive directedness.' (50). According to Richardson, our deepest values are expressions of biological drives that are not different in kind from those at work in all organic life. This organic directedness is present in us due to the workings of evolution such that our drives and our drive capacities are selected and layered into us through our genetic line (51).

Richardson's naturalist interpretation of Nietzsche's approach to values goes hand in hand with a particular ontology of values that understands them in predominantly internalist terms. This means that Nietzsche thinks that values are perspectival and dependent on acts of valuing (1-2). Values, according to this view, are valueds. They are signs deposited in the valuer and in the world (18) for the drives to steer by. According to Richardson,

\footnotetext{
${ }^{4}$ Emden 2014.
} 
Nietzsche, at times, leans towards externalism as a result of a desire on his part to establish that his values are valuable independent of his valuing them. Although such leanings towards appealing to 'real' values (29) are ultimately missteps on Nietzsche's part, he needs some way, it is argued, from within his internalist framework, to establish that his values are valuable and should be valued independently of his merely valuing them (26-7). In the context of his internalism and perspectivism, Richardson claims, this justification must appeal to values that 'he and we (his readers) already have.' (27) These are the values of truth and power, which are so deeply embedded in us that 'there's no prospect of amending them to avoid his arguments.' (28) Still, since the values of truth and power are 'external' to my first-order valuing and are good independently of it, they play an externalist role within Nietzsche's internalism. He considers his values as honest and truthful, not because they correspond to 'real goods independent of his valuing' but rather in the sense that 'he values them while seeing and facing the truth about them.' (28) Nietzsche's ability to combine externalist-like constraints from within an internalist approach to values provides the basis of his proposed transvaluation and reformation of our values. Particularly, Richardson argues that Nietzsche's incorporation of truths about our values gives us reason to revise our values (26). His interpretation sees Nietzsche adopt a dynamic account of valuing where I come to see my values as in a process of improving according to the criteria of power and truth (29). Since power is life's ultimate meta-value, he argues, 'incorporating the truth will let us make values better signposts for the growth we ultimately want them for.' (27)

Central to improving our values, according to Richardson's Nietzsche, is the need to realign our agential, worded and conscious values with our animal valuing. The latter resides in the activity of our drives whilst the former entails the imposition of external societal interests on the drives. Agential values are imposed on our drives in order to tame our natural drives for social life by inculcating 'the habit of obeying external norms' (32). The external posits of societal agential values, Richardson argues, is really only a '(deeply settled) bad habit' that can be ultimately overthrown (32). It can be overthrown by coming to understand how the unity of the self is constituted by hierarchical relations of our natural drives and reversing the relation between agential values and our natural animal values. That is, agency needs to 'learn to tend to the drives' and be induced 'to take the side of the other drives and not just of that taming interest.' (110) Only in this way will we break from the oppression of morality and cease our practice as reflective agents of imposing supposedly external and real values on ourselves (111). The agential drives must be brought to serve the natural drives as a synthetic unit governed by a dominant drive and a 'mutual recognition' (113) amongst the drives that make up the unit. Accordingly, we must learn to recognize the importance of the 'wicked drives', not by indiscriminately unleashing them, but by directing them to a positive productive end (111). The drives, for Nietzsche, in Richardson's view, are not brute mechanical causes but, rather, they are intentional and capable of 'communicative intelligence' (113). It is this intentional and communicative intelligence that makes them capable of forming a synthetic unit constituted by a 'shared understanding' amongst the constituent members (113). Agential drives can be made one's own, then, by bringing the constitutive perspectivity of the drives and the animal self to consciousness (113). In this way, we can become truthful about the status of our values, that is, that they do not correspond to something external. A healthy 
self, such as is the unity of the drives under the rule of a dominant drive, also aims better at power (75).

According to Richardson, inherited values can be brought into alignment with my synthesis of drives by re-aiming them to effectively guide my own thoughts and behaviour (452). However, his proposed revaluation of values also involves incorporating these values into the practices of some group and not just into my own habits. In so doing, the value 'inserts itself into the group's or community's norms.' (454) The point of redesigning norms is to 'enhance human's power'. By power here, Nietzsche, it is argued, has in mind spiritual growth according to which the human becomes able to control its values whereas before it was controlled by them. Specifically, Nietzsche wants to re-value norms by demoralizing them and by incorporating this truth into the herd (457). In so doing, the herd, by virtue of their commitment to these norms, come to view themselves as living a higher life than before and of being "at the cutting edge of humanity"' (460). The 'new nobility', according to Richardson, constitute a higher herd that commands the 'new herd' (471) paternalistically. That is, the new nobility sees what's good for the herd in a way that the herd doesn't see for themselves (473).

In addition to nobles and the herd, Richardson argues that Nietzsche envisages a third type, the individual, along his 'ladder of human types' (467) who posthumously commands the noble rulers who, in turn, command the ruled herd. The individual is the genuine philosopher who creates values 'not just for their own particular use, but also for a social group.' (470) These are superhuman values that represent what humans need to aspire to and what needs to be achieved at an individual level and ultimately incorporated into our social existence (481). According to Richardson's Nietzsche, human becomes superhuman by incorporating the truth that it is itself an arrangement of drives and affects and that the sole authority of its values lies in 'their fitness for its own case.' (482) Acknowledging these truths makes the superhuman free. The traditional idea of freedom is transformed by the superhuman such that freedom is no longer understood to be a 'first cause' but, rather, entails freedom from illusions about agency, from bad conscience and guilt, and from 'at least some of the need to match their values to others.' (482) In Richardson's view, Nietzsche's appeal to the superhuman culminates in a new religion that appeals, not to authoritative commands, but 'a certain affectivity or pathos.' (495) It involves a 'feeling of power' in relation to both itself and everything around it. This feeling is one of 'love of the world, including oneself (495), 'a wise gladness, a love for the world that sees it as it is.' (500) The divine perspective that sees all things as good and as part of the whole (506) is a maximal state in the development of the will to power articulated in the doctrine of the eternal recurrence. The eternal recurrence, it is argued, whilst not true, is nonetheless not a fiction because it articulates basic truths about my condition and the world in metaphors (524). Principally, it articulates in metaphor the truth that 'this is my one and only life, that it is fated by the whole history of the world and that it is essentially a process and becoming' (525). In so doing, Nietzsche's metaphor of the eternal recurrence allows us to continue to value whilst knowing that our values are valueds and not commands from an external authority. 


\section{Nietzsche's naturalism}

From grounding Nietzsche's internalism in biological drives and affects to its culmination in eternal recurrence, the persuasiveness of Richardson's interpretation of Nietzsche's approach to values depends on the reader buying into the non-essentialism that informs his understanding of Nietzsche's naturalism. At the very heart of his naturalism, for Richardson, is an evolutionary-informed and non-essentialist account of the drives and the values they create as signs to steer by. Drives, he argues, 'are dispositions selected to pursue activities by the guidance of signs - that also adjust these signs on the basis of past felt success.' (101) The drives are intentional but not anthropomorphic on the grounds that intentionality is grounded in biological dispositions that are selected by evolutionary forces for particular ends. The "responsive "towardness" of these dispositions is 'the root of the drive's active aiming' (89). In Richardson's view, although the drives are passively shaped by evolutionary forces, they are designed to aim actively and intentionally (95). Drives 'are thereby "intelligent," but in a different way than agents are taken to be - a way that is easier to attribute to animals (and even plants) than is agency.' (101) It follows from this argument that the drives are not 'mere causal tendencies' (82) but rather 'are selected by a kind of purposive intent' (93). According to Richardson's reading, then, all organic life, is intentional although not necessarily conscious.

Whilst it is correct that Nietzsche understands the drives as dispositional, their dispositionality, contrary to Richardson, seems to be grounded in their intentionality and it is far from obvious that their intentionality is to be understood in non-essentialist terms as selected by evolution. Rather, the drives, for Nietzsche, are primarily intentional wills to power. Indeed, he takes the intentional to be the mark of the dispositional by making psychology his starting point in assessing the continuity of the human mind with nature (BGE §23; §36). Moreover, he extends this practice of taking the intentional to be the mark of the dispositional beyond biological life to include natural causality generally. Richardson is keen in this book to push the idea that the will to power applies to biological life only, thus avoiding debates in Nietzsche studies about the will to power as articulated in BGE §36. In this passage, Nietzsche asks whether the will to power can be taken as an explanation of the physical world, biological life and psychology. That he extends it to biological life and psychology is not doubted by Richardson whilst he sidesteps the issue of Nietzsche's extension of the thesis to non-biological nature by dismissing it as something that Nietzsche thinks is 'dispensable' (47). However, even if one wants to avert their gaze from BGE \$36, it is clear from GS \$360, that Nietzsche attributes driving and willing to non-biological causes. Offering an essentialist, instead of a mechanical, account of causality, he argues that the behaviour of causal powers stems from their essential driving or willing natures. This means that the explosion of a powder, for example, stems from the powder's inherent capacity to explode and is not dependent on an extrinsic stimulus, such as that provided by the lighting of a match (GS \$360). Nonetheless, Nietzsche points out that the extrinsic stimulus can play a guiding role by providing conditions that facilitate the manifestation of the powder's inherent capacity, a factor which highlights the dispositionality of causal powers. The modality of dispositions is such that whilst they tend towards their outcomes, their manifestation is neither necessary nor contingent. Causal powers are dispositional for Nietzsche because although they 'will' to manifest themselves (GS \$360), their manifestation is not necessary in cases where 


\section{Nietzsche on Power and Value}

facilitating conditions are lacking. However, although it is not necessary, the manifestation of the explosive powder is not contingent either. This is because its explosion stems from the powder's essential causal power and not from the facilitating or guiding conditions, primarily. Thus, for Nietzsche, causal powers are intentional and modally dispositional, and their intentional directedness is the marker of their intelligible inner - essentially powerful - natures (BGE \$36).

Nietzsche makes it clear that he understands the causality of the human will similarly to physical causality. The human will, he argues, is a complex phenomenon involving hierarchical relations between intentionally directed drives. Moreover, the relations between the commanding and obeying drives that constitute the will are dispositional. That the causality of the will is dispositional is clear from his claim that the will does not necessitate its effect. In BGE \$19, Nietzsche tells us that although a dominant will may command a particular action that reflects its nature and is, accordingly, not contingent, the action may not ensue due to a lack of cooperation or obstruction on the part of the other wills under its command. It might be argued here, though, that Nietzsche describes weakness of will in BGE $\$ 19$ and that weakness cannot be understood as a powerful capacity. However, we notice the same dispositional modality in the case of the strong will of the sovereign individual who has achieved 'mastery over himself' and is permitted to make promises (GM II \2). The will of this individual, whilst characterized as strong, is not unfailing. Still, their strength of will stems from their ability to 'digest' their 'misdeeds' (GM III \16; BGE \230), which ensures that their occasional errant actions do not prevent them from executing their will for the most part. The 'independent long will' of the sovereign individual (GM II \$2) holds together multiple drives as an integrated unity in the long term, reflecting the powerful influence of a dominant drive. The will of the sovereign individual is dispositional, then, in the sense that it tends towards its outcomes which, reflecting the nature of the dominant drive, are not contingent, but which are not necessitated either on those infrequent occasions when errant drives prevent their realization.

The above account of dispositions is quite different from the dispositions to which Richardson appeals because, for him, dispositions are biological and selected forms of responsive towardness (89). But his account of responsive towardness does not capture the inherent activity and intentional directedness of Nietzsche's drives and the manner in which that essential willing directedness is the basis of their modal dispositionality. Richardson also fails to capture how, for Nietzsche, active willing and intentional directedness is inherent in all natural causes and not just biological drives. Still, although Nietzsche takes the intentional to be the mark of the dispositional, he might be better advised, in accounting for the human being's continuity with non-human nature, both biological and non-biological, and whilst avoiding the anthropomorphism that he (GS \$109) and Richardson, on his behalf (49), worries about, to focus on the dispositional as the root of the intentional. Nietzsche understands 'dammed-up' dispositions as dischargeable properties that involve intentional willing or driving (GS \$360). But it is arguably the case that since, for Nietzsche, the modality of intentions is dispositional, as we have seen in the case of natural causal powers and the human will, dispositions explain intentionality 
rather than the other way around. ${ }^{5}$ Such an acknowledgement would allow Nietzsche to hold, as Richardson wants him to, that psychological behaviour can be understood naturalistically and as operating beneath the level of consciousness. Still, although the dispositional can achieve much of what Nietzsche wants, it need not be construed in the non-essentialist and evolutionary terms that we meet in Richardson's book. Indeed, the fact that drives are dispositional at all points to a more essentialist account than Richardson's neo-Darwinian interpretation is willing to allow. Understood as being dispositional, drives need not succeed in manifesting or attaining power to be considered powerful. The nobles that have been forced underground in modernity and to whom Nietzsche is at pains to address and awake from their slumbers in BGE are still powerful or 'higher' even in their dormant state (BGE \$274). This means that, despite Richardson's telic account of power in Nietzsche, power is also something that the drives are rather than merely something that they become.

Richardson defines power to which all life aims as a process of ascending from lower to higher power. Understood as growth in control, he writes that power is 'a process of transition from less to more and from lower to higher.' (71) The notion of transitioning from lesser to higher suggests that drives are already a given quanta of power. Nonetheless, Richardson insists on interpreting Nietzsche's reference to quanta of power in telic and non-essentialist terms by interpreting quanta of power as a state that is attained. What is attained, he argues, is strength, which is a 'capacity for control' (465). Richardson highlights that there is an ambiguity in the notion of a capacity. He asks, for example, whether we should take the capacity to command to mean that X has the capacity to command $\mathrm{Y}$ such that $\mathrm{X}$ could over time and with effort succeed in making $\mathrm{Y}$ obey, or whether we mean that $\mathrm{X}$ has already brought $\mathrm{Y}$ to submission and that $\mathrm{X}$ only has to issue commands to $\mathrm{Y}$ to make $\mathrm{Y}$ obey (72). The choice is whether to understand a capacity in dispositional and potentialist terms or whether to understand it in actualist terms. Richardson interprets it in actualist terms and claims that control is 'a capacity' that is 'very close to actual commanding' (72). I think this is a mistake. We saw in our examination of Nietzsche's account of the causality of the will and in his account of the sovereign individual that the will's commands are, in both cases of strong and weak will, dispositional. That is, commanding is, for Nietzsche, a dispositional rather than an actualist success term and is more adequately captured by the first, dispositional, use of the term highlighted by Richardson above. The dispositionality of the will to power, as I have argued, indicates that the will is already a given quanta of power. As such, the will to power of drives preexists acts of evolutionary selection. One could never accuse Richardson of being unaware of this problem and, in fact, he acknowledges it openly in his earlier Nietzsche's New Darwinism. There he claims that sometimes Nietzsche holds that the drives as wills to power provide the raw material for selection rather than the drives being the result of selection. He writes: 'in his metaphysical moods, Nietzsche thinks that although drives may well be shaped by selection, this selection works on a raw material supplied to it by and as will to power itself. ${ }^{6}$ Nonetheless, he downplays the essentialism in Nietzsche's will to power in this recent book in his efforts to provide a consistent, non-essentialist and

\footnotetext{
${ }^{5}$ See, Anjum, Rani Lill, Svein Anders Noer Lie and Stephen Mumford 2013 (240) for such an argument outside of Nietzsche studies.

${ }^{6}$ Richardson 2004 (46).
} 
palatable interpretation of Nietzsche for a contemporary philosophical audience. But, even his concession in his earlier book that the will to power may precede selection, underplays Nietzsche's essentialism by construing it as formless raw material to be worked upon by evolutionary forces.

Even though Richardson's efforts to show that the drives, for Nietzsche, are richly intentional rather than mere dispositional tendencies or causes in a mechanical sense, is correct, he consistently deflects attention away from Nietzsche's causal essentialism. While he certainly emphasizes the role that the drives play in steering other drives in the direction of its own values (164), Richardson understands this steering activity as evaluatively focussed and as exhibiting intentionality, which, he claims, opens up a shared space of meaning between the drives. However, the fact that the drives exhibit intentional directedness does nothing to raise them beyond the level of the causal or dispositional. This is because Nietzsche, as we have already seen, has a richer metaphysics of causality than that of mere mechanical pushes and pulls that leads him to take the intentional to be the marker of the dispositional or causal. Significantly, understanding the causal nature of the drives is central to understanding how the drives are themselves powers and not just directed towards attaining power. Nietzsche makes the causal nature of the will to power evident in BGE \$36 when he describes it as an efficient cause and inner will to force. ${ }^{7}$ According to Nietzsche, the drives are, essentially, causal powers or capacities and, rather than being inchoate, they are fundamentally capacities to do particular things. This is evident in GM when he writes that the little lambs and the bird of prey are what they are essentially. It belongs to the bird of prey's essential nature, for example, to 'snatch up little lambs for themselves' (GM I \$13). Similarly, it is the nature of explosive powder in GS $\$ 360$ to explode under facilitating conditions. As such, the drives are not instances of directionless energy that acquire evaluative focus through selection. Moreover, each drive is a particular quantum of power and the values of the drive reflect the particular quantum of power that the drive is (WP \$675 KSA 13: 11 [96]). That is, the value judgements of the drives, reflect their particular and essential measure of power to act in the world (GM I \$13). Accordingly, the value judgements of the lamb and the bird of prey reflect their particular and essential measure of power such that the lamb, for example, appraises the bird of prey in negative evaluative terms because the bird of prey presents an insurmountable obstacle to its own essential activity (GM I \$13). The evaluative activity of the drives is thus informed and fuelled by the particular quantum of power that they are. Understanding this is pivotal to understanding the relation between the drives that constitute the self and, indeed, the relation between the drive constituted self and the world.

\section{Causal essentialism, the self and the reformation of norms}

Richardson's Nietzsche holds that the constitution of the self involves a synthesis of drives by a dominant drive, in addition to taking ownership of values that were originally installed in the self by an external force. According to this view, we must face up to the truth about the perspectivity of values by learning to recognize their perspectivity whilst continuing to value and, consequently, avoiding the spectre of nihilism. To understand the perspectivity of my values is to 'recognize the others that speak in them' (431). That is, I must recognize

${ }^{7}$ I respond to objections to BGE 36 in Doyle 2018 (128-143). 
that values have been installed in me without my knowing it and yet continue to value but for reasons of my own that reflect who I am in my drives independent of the influence of outside societal forces. Now, Richardson interprets synthesis of drives by a dominant drive non-essentially. Although he acknowledges Nietzsche's fatalism, which holds that the dominancy of a drive is a matter of fate and that our particular drive constitution is given rather than made, he claims that 'mainly I think he means something different'. This is often Richardson's response to passages that don't fit the overarching interpretation that he wants to offer. The something different to a fatalistic account of the drives holds that drives can be created by 'making a certain habit of effort'. Specifically, he claims that the many drives that contribute to the constitution of the self create the dominant drive that unifies the drives as a self 'out of the many "local" habits of effort that make up one's intentional stream.’ (422)

Richardson argues in this way in support of his interpretation that the intentionality of the drives lends them an intelligence beneath the level of consciousness whereby they can judge from a shared intentional space whether externally imposed values are actually good for 'the self' that they constitute (428). He appeals to EH 'Clever' $\$ 9$ to support his nonessentialist account of the acquisition of a dominant drive, describing Nietzsche's argument as follows: 'He had been developing abilities that would serve this project without realizing that he was doing so. The drive for this project is formed by a unification of those disparate abilities - carried out by those abilities themselves. Nietzsche makes it clear that it was not himself as subject or agent who accomplished it.' (423). Whilst I agree that Nietzsche denies that an agent independent of the drives brings about the unification or synthesis of the drives, I cannot see where in this passage Nietzsche suggests that new abilities were being created by the drives. Rather, he says that a particular drive comes to dominate without us being consciously aware of it. He describes the ripening of abilities and while there is a reference to the dominant drive constructing the 'ancillary capacities', the construction entails 'preparing' individual abilities for the role that they will play in relation to the whole. The passage describes the process whereby the dominant drive or 'organizing idea' synthesizes the multiplicity of drives hierarchically thus asserting its dominance in the unit that will become the self. But Nietzsche is not suggesting that the dominant drive is created by the other drives and their interactions. Rather, as indicated in BGE, he thinks that the multiple drives that constitute the self are given or fated rather than made, writing of 'our spiritual Fatum' and "unteachable essence, way "down there" (BGE \231). And, he is suggesting that the dominant drive is dominant because of its greater causal power to herd the other drives to act in the service of its dominant evaluative perspective. This is strongly conveyed in his reference to an 'Order of rank among capacities (Rangordnung der Vermögen)' (EH 'Clever' \$9).

Richardson stresses that the relation between the commanding and obeying wills that constitute a unified self is not one of brute force or causality, but rather one of shared understanding or meeting of minds (104). More fundamentally, though, these relations reflect the quanta of power that a drive is and any 'understanding' or arrangement between them reflects what each drive has the capacity to do in the circumstances or relationships in which it finds itself. This is not to deny the claim that Nietzsche thinks that the drives can have reasons or understanding because I think he does allow that (GM III \$12; WP §387 KSA13: 11 [310]). Still, the reasons or understanding that govern the synthetic unit of drives that is the self are formulated by the dominant drive and reflect the causal power 


\section{Nietzsche on Power and Value}

of the dominant drive. Nietzsche writes that 'Which of the groups of sensations within a soul come alive, most quickly, to speak or command - that decides the overall hierarchy of the soul's values and ultimately determines its table of goods.' (BGE \$268) Of course, the obeying drives must be given an opportunity to express themselves rather than be extirpated if the unit is to be a healthy one but that opportunity is one that is afforded by the dominant drive out of an abundance of power on the latter's part. As he further writes: 'What determines rank is the quantum of power that you are; the rest is cowardice' (WP \858 KSA 13: 11 [36]). ${ }^{8}$ That relations between dominant and subordinate drives involve causal relations between the two orders of drive is evident in Nietzsche's claim that their relations entail, not bottom-up acts of recognition of the dominant drive's normative authority on the part of subordinate drives, but rather top-down acts of 'appropriating, injuring, overpowering those who are foreign and weaker; oppression, harshness, forcing one's forms on others, incorporation, and at the very least, at the very mildest, exploitation' on the part of the dominating drive. Exploitation, he claims, is not part of a decadent or imperfect, primitive society: it is part of the fundamental nature of living things, as its fundamental organic function; it is a consequence of the true will to power, which is simply the will to life.' (BGE \$259) Nietzsche’s description of hierarchical relations as exploitative is not a denial that subordinate drives may actively cooperate with the dominant drive (WP $\$ 636 \mathrm{KSA} 13: 14$ [186]), but it is a recognition that their doing so follows from the quest, on the part of the subordinate drives, for optimal conditions under which they can manifest themselves (GM II S7). In the context of the hierarchical structure that is the self, these conditions are shaped by the superior causal power that the dominating drive is essentially. According to Nietzsche, the hierarchical unity of the self is achieved through the competitive causal interaction of the drives, such that the dominant drive determines whether the subordinate drives under its command are gratified by being redirected into new 'channels' or curtailed through the use of various causal mechanisms (D \$109).

Nietzsche's causal essentialism matters because it impacts on issues such as our ability to change or reform our values especially in light of the reasons offered by others. Richardson paints a very optimistic picture about the possibility of evaluative reform in the book when he discusses the paternalism of the higher types in relation to the lower types. He writes that 'Nietzsche thinks that the elite's "paternalism" will manifest in an effort to give the herd norms that aim members better at their own growth.' Paternalism can work, according to this reading, by the herd itself coming to 'recognize rank order against the natural tendency of their own strong herd-instinct.' (473) Thus, in Richardson's view, 'Nietzsche anticipates a greater "solidarity" in the new society: all levels share the project to live a higher life - to carry the human kind ahead.' In particular, the new herd sees itself, not at the bottom of the current hierarchy but, rather, as standing 'at the so far top of the ladder of human lives.' (474)

However, the optimism that Richardson attributes to Nietzsche relies on our understanding drives and their values non-essentially. Understood in essentialist terms, by contrast, we find that even if the higher type knows what is good for the lower type, the lower type may still lack the requisite power or ability to act on their advice. The inability to do so is precisely what differentiates Nietzsche's lower from higher types. In Z Nietzsche warns against willing beyond one's powers, claiming that 'there is an evil falsity

${ }^{8}$ It is to be noted that Richardson cites the same passage (465) but doesn't draw out this implication. 
about those who will beyond their powers' (Z: 4 'Of The Higher Man’ \$8). Moreover, the lower type's fundamental lack of power in comparison with the higher type rules out, for Nietzsche, the possibility of meaningful communication between the two. In $Z$ he explains to his 'brothers' that it is impossible to communicate with the 'mob' of the market-place, writing that 'What are the market-place and the mob and the mob's confusion and the mob’s long ears to me.' (Z: 4 'Of the Higher Man’ \$1) Since the lower types cannot act on what they are told is good for them, it falls to the higher types to institute causal societal mechanisms to bring about a reconfiguration of the drives in the lower types that is consonant with their inherent capacities. It is telling that Richardson cites BGE $\$ 221$ where Nietzsche writes that 'One must force (zwingen - my emphasis) moralities to bow first of all before rank-order...'

Richardson certainly shows his awareness of the role of causality in Nietzsche when he writes of the metaphor of the eternal recurrence as revealing 'the positive truth that my life is knotted so firmly into the world by a web of causal connections that tie me to everything,....the intricate causal necessity that settles everything I do.' (524) Nevertheless, the causality that he refers to here is of the non-essentialist evolutionary kind. According to Richardson, the causal necessity that the metaphor of the eternal recurrence draws our attention to is that my life has been 'shaped by the whole world around me and by all the past of that world.' (518) But, contrary to Richardson, Nietzsche’s causal essentialist account of the drives as will to power sees them, primarily, as shaping rather than shaped forces (WP \$656 KSA 12: 9 [151]). Quanta of power certainly respond to their environments and can be curtailed in their activities by this environment, but they are, nonetheless, a particular, essentialist, measure of power. A quantum of power, whether it be strong or weak, is its 'essence' and 'unavoidable and undetachable reality' (GM I \$13).

\section{Beyond constructivism and internalism}

Understanding the essential causal or powerful character of the drives is also important because it casts doubt on Richardson's claim that Nietzsche is a constructivist about value. Richardson's constructivism understands values as 'creations' or 'made things' (18) of 'drive-valuing' (82). He describes values as being deposited in the valuer and in the world, as valueds of drives' valuing, such that the latter causes our values (18). However, our drives are understood in non-essentialist terms as selected to play a particular function by evolution or social forces external to the drive. It follows, then, that if Richardson is right about values being constructed, they are in fact constructed by evolutionary or external social forces. This follows even if we accept Richardson's claim that the drives have been selected to actively aim or have goals (88). For values to be constructed by the drives rather than these external causes, a drive must be understood in essentialist terms as itself a quanta of power. But, if we understand drives in the latter essentialist sense and try to say that they cause our values, we confront a problem. According to Nietzsche, forces and their effects are not ontologically distinct. The doer and the deed are one and the same (GM I \$13; WP \$675 KSA 13: 11[96]). Moreover, as Richardson argues later in the book, in response to Katsafanas who claims that the drives are mere dispositions that do not in themselves value but produce evaluative psychic states, drives are always already evaluative (93). If this is the case and if the doer and the deed are not ontologically distinct, then, it seems, values cannot be detached from the drive's valuing. Rather, on the grounds that

'valuating is itself the value and jewel of all valued things' ( $\mathrm{Z}$ : I 'Of the Thousand and One 
Goals'), values are ontologically indistinct expressions of the evaluative fabric of the drive's activity. Accordingly, values are creations by virtue of being ontologically indistinct expressions of the quanta of power that a drive is and are not to be found in the world independently of that evaluating activity (GS \$301; Z: I 'Of the Thousand and One Goals'). For Nietzsche, then, values are more suitably characterized as valuings rather than valueds. Running together evaluation and value, values, as valuings, are expressions of the drives' selectively or evaluatively focussed forms of dispositional action in and interaction with the world. In Nietzsche's view, the drives are always acting, even if not optimally, as they seek out conditions conducive to their manifestation (GM III \$7). They are dispositional, however, to the extent that they are prevented by the countervailing activities of other forces from optimally manifesting their powerful natures. Still, Richardson worries that aligning values too closely with evaluation will leave unexplained how values can persist after acts of evaluation have taken place (15). However, values persist for Nietzsche because the perspectival evaluative stance or ways of looking "into the world" that informs acts of evaluation persist as physiological conditions of particular forms of life and in the language in which they are expressed (BGE \$20).

This brings me to another point. Despite Richardson's aim to examine Nietzsche's own picture of the world and of us (humans) in our relation to it' (x), his description of our values in internalist terms threatens to commit Nietzsche to a dualist understanding of the relation between the evaluative self and its world. Presumably, Richardson's efforts to ground Nietzsche's approach to values as creations of the drives in biology and his account of the drives as responsive to the environment is intended to avoid dualism. But little is said in Richardson's account about the drive's environment other than to describe its relation to other drives and to external social forces that the drive constituted self comes to internalize and ultimately align with its natural drives with a view to becoming a healthy self (108). Richardson considers Nietzsche's appeal to a standard beyond the valuer as an unfortunate externalist slippage and instead places his interpretation of Nietzsche's approach to values in the Humean subjectivist camp (2). It seems to me, though, that the Humean comparison is not quite apt. This is because the drives, for Nietzsche, are powers or capacities for action. Their activities are not divorced from or projected onto an evaluatively neutral world but take place in the midst of the world, which itself is to be understood in terms of the will to power and as evaluatively responsive to our actions.

According to Nietzsche, the evaluatively focussed activities of the drives are immersed in and interact with the world. This is because, values as ontologically indistinct expressions of the drives, are modes of action in the world (WP \$567 KSA 13: 14 [184]) that, like all natural causes, are modally dispositional. He claims that the apparent world, which is the real world (WP \$566 KSA 13: 11 [50]), is an evaluative world (WP \$567 KSA 13: 14 [184]), where values are forms of action and reaction in it. Although the world is for us 'viewed according to values', Nietzsche tells us that the world is constitutively perspectival in that 'Every center of force adopts a perspective toward the entire remainder, i.e., its own particular valuation, mode of action and mode of resistance' such that 'Reality consists precisely in this particular action and reaction of every individual part toward the whole' (WP \$567 KSA 13: 14 [184]). Reality, then, is irreducible to any one perspective or type of perspective. Since Nietzsche warns against taking the human perspective as constitutive or universal, the world in which we act must be independent of human evaluations. He writes that 'to demand that our human interpretations and values should be universal and 
perhaps constitutive values is one of the hereditary madnesses of human pride.' (WP \565 KSA 12: 6 [14]) That the activity and reactivity that constitutes reality as a whole is not reducible to human evaluations is further evident from Nietzsche's denial that man is the measure of all things (BGE \3) and from his efforts to de-humanize the natural world (GS $\$ 109)$, and to understand the human being as an acting part in nature (BGE \$230). As an evaluative acting part, the human being both acts and reacts in the world that is, in turn, the sum of all, and not just human, actions and reactions (WP \$567 KSA 13: 14 [184]). However, although irreducible to human evaluations, Nietzsche's view that both the world and the evaluating human being should be understood in the same essentially powerful terms, indicates that the world's relationship to human evaluative activity is not a passive one. Rather, both human beings and the world in which they are naturalistically immersed should be understood as will to power. Richardson clearly wants to avoid talking about non-biological nature in terms of the will to power. However, even if we restrict the application of the will to power to biological life, it is clear that the world in which evaluative human beings act is not itself evaluatively inert. That it is not, is evident in Richardson's claim that all organisms value. The evaluatively ert world in which the human valuer acts, then, presents affordances or resistances to human evaluatively-laden actions. As dispositional modes of action in the world that either facilitates or hinders those valuefuelled actions, human values are neither internal nor external. Rather, as expressions of the drives, they act in and interact with the world by seeking out and attempting to overcome resistance from other, not necessarily human or reducible to the human, actors in the world (WP \$656 KSA 12: 9 [151]). Overcoming resistance is the measure of a power's strength and success and, in Nietzsche's view, in the case of human beings, constitutes happiness (AC \$2). In his discussion of the eternal recurrence (500), Richardson writes of the need to love the world. But, it should be noted that Nietzsche also refers to 'how accommodating' and 'full of love' the world is towards particular evaluative types (GM II \$24), suggesting that the world in which the human evaluating organism acts and interacts is not evaluatively neutral to our value fuelled interactions with it. Constructivism as an interpretation of Nietzsche has recently been proposed as a way that one can avail of the resources of realism or externalism in the form of exerting a constraint on what we are justified in believing from within an internalist or subjectivist framework, ${ }^{9}$ and Richardson's interpretation presents Nietzsche in a similar vein. But, Nietzsche doesn't need to avail of the resources of constructivism to help himself to externalist constraints without making externalist ontological commitments. This is because his account of the drives and their values as dispositional forms of action in the world side-steps the dualism of inner and outer in the first place. ${ }^{10}$ While Richardson is very alert to the role of action in Nietzsche's philosophy, he, nonetheless, fails to adequately draw out the non-dualist implications of it.

\section{Conclusion}

In sum, as ingenious and compelling as Richardson's argument is in many respects, it depends on a neo-Darwinian and non-essentialist account of Nietzsche and the drives. Although the overarching interpretation makes sense of much of what Nietzsche wants to

\footnotetext{
${ }^{9}$ Silk 2015.

${ }^{10}$ In this way, Nietzsche also side-steps the idealism that Richardson worries may follow from aligning values too closely with valuing (15).
} 
do and achieve, as Richardson understands those aims, it is nonetheless in tension with the obviously more essentialist aspects of Nietzsche's arguments regarding power. Despite the emphasis on power throughout the book, there is a notable tendency to acknowledge, while inadequately addressing, possible alternative interpretations of Nietzsche, most especially when those interpretations lead to essentialist and metaphysical commitments. This tendency is very obvious in the dismissal, with inadequate justification, of BGE \$36 and also of Paul Loeb's account of the eternal recurrence as a true cosmological thesis (511). Richardson is inclined to adjudicate interpretive tensions posed by Nietzsche's writings by appealing to what he thinks Nietzsche really means. Although I am very much in favour of offering rational reconstructions of historical figures if it serves to make their arguments coherent and cogent, I find Richardson's appeal to what he thinks Nietzsche means in the book frustrating in light of the interpretive complexity surrounding his notion of power and the textual support for an alternative essentialist interpretation. At the beginning of the book, Richardson tells us that he aspires 'to interpret and synthesize Nietzsche's ideas into the strongest positions I can and to leave the assessments of them to readers' (xiii). Although he leaves the assessment of the arguments to readers, it is clear that the arguments, as Richardson presents them in the book, are an expression of his preferred Nietzsche. I am not ultimately convinced that his preferred Nietzsche is the real Nietzsche and I would have liked less gaze averting when it comes to attending to the essentialist aspects of his appeal to power. Nonetheless, Richardson's neo-Darwinian and non-essentialist reading will make Nietzsche's appeal to power more palatable to those commentators who baulk at possible essentialist and metaphysical interpretations of it. The latter audience is certainly rather larger than the alternative and if one accepts Richardson's neo-Darwinian and non-essentialist starting point, the book holds together as a comprehensive, persuasive, illuminating and detailed interpretation of Nietzsche's naturalist approach to value. My reservations notwithstanding, it is, without doubt, a highly significant contribution to Nietzsche studies.

\section{Works Cited}

Anjum, Rani Lill, Svein Anders Noer Lie and Stephen Mumford, 'Dispositions and Ethics,' in R. Groff and J. Greco (eds.), Powers and Capacities in Philosophy: The New Aristotelianism. Routledge, 2013, 231 247.

Clark, M. and Dudrick, D. The Soul of Nietssche's Beyond Good and Evil. Cambridge University Press 2012.

Doyle, T. Nietzsche's Metaphysics of the Will to Power: The Possibility of Value. Cambridge University Press 2018.

Emden, C.J. Nietzsche's Naturalism: Philosophy and the Life Sciences in the Nineteenth Century. Cambridge University Press 2014.

Nietzsche, Friedrich, Beyond Good and Evil. Trans. Marion Faber. Oxford University Press 1998.

On the Genealogy of Morality. Trans. Maudemarie Clark and Alan J. Swensen. Hackett Publishing Company 1998.

Ecce Homo. Trans. R. J. Hollingdale. Penguin 1992.

The Anti-Christ, included in Twilight of the Idols/The Anti-Christ. Trans. R. J. Hollingdale. Penguin 1990.

The Gay Science. Trans. Walter Kaufmann.Vintage Books 1974.

Thus Spoke Zarathustra. Trans. R. J. Hollingdale. Penguin 1969.

The Will to Power. Trans. R. J. Hollingdale and Walter Kaufmann. Vintage Books 1968.

Sämtliche Werke. Kritische Studienausgabe, 15 volumes, Giorgio Colli and Mazzino Montinari (eds.), Berlin and New York: Walter de Gruyter 1967-1977.

Richardson, J. Nietzsche's New Darwinism, Oxford University Press 2004. 
Doyle 129

Silk, A. 'Nietzschean Constructivism: Ethics and Metaethics for All and None' in Inquiry: An Interdisciplinary Journal of Pbilosophy, 58 (3), 2015. (244-280). 